НАУКОВИЙ ВІСНИК

Cientific messenger or LLiv National Liviversity of

(1)

$\sqrt{3}$

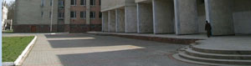

СЕРЯя: ВЕТЕРИНАРНН НАУКИ

Том 23 № 101

2021
Науковий вісник Дьвівського національного університету ветеринарної медицини та біотехнодогій імені С.3. Гжицького. Серія: Ветеринарні науки

\author{
Scientific Messenger of Lviv National University \\ of Veterinary Medicine and Biotechnologies. \\ Series: Veterinary sciences
}

UDC 636.52/.58.09:614.31:637.5

\title{
Dependence of broiler chick meat quality on culture methods
}

\author{
V. V. Hunich ${ }^{1}$, Yu. S. Stronskyi ${ }^{2}$, Zh. B. Koreneva ${ }^{1}$, A. I. Holovanova ${ }^{1}$, E. V. Sultanovskaya ${ }^{3}$ \\ ${ }^{1}$ Odessa State Agrarian University, Odessa, Ukraine \\ ${ }^{2}$ Stepan Gzhytskyj National University of Veterinary Medicine and Biotechnologies Lviv, Ukraine \\ ${ }^{3}$ Laboratory of veterinary and sanitary examination of the market "Cheryomushki" LLC "Yurtal", Odessa, Ukraine
}

Article info

Received 18.01.2021

Received in revised form 19.02.2021

Accepted 20.02.2021

Odessa State Agrarian University Panteleymonyvska Str., 13, Odessa, 65012, Ukraine.

Stepan Gzhytskyi National University of Veterinary Medicine and Biotechnologies Lviv, Pekarskaya Str., 50, Lviv, 79010, Ukraine.

Tel.: +38-067-720-26-66

E-mail:facvetmed@ukr.net

Laboratory of veterinary and sanitary examination of the market "Cheryomushki" LLC "Yurtal", Odessa, Ukraine.
Hunich, V. V., Stronskyi, Yu. S., Koreneva, Zh. B., Holovanova, A. I., \& Sultanovskaya, E. V. (2021). Dependence of broiler chick meat quality on culture methods. Scientific Messenger of Lviv National University of Veterinary Medicine and Biotechnologies. Series: Veterinary sciences, 23(101), 86-92. doi: 10.32718/nvlvet10115

For research, purchased on the market in Odessa, the carcasses of broilers TM "Nasha Ryaba" and private farms in the Odessa region, Ovidiopol district. In markets laboratory, we have determined a reference method for determining the concentration of hydrogen ions $(p H)$. In the samples studied by us, the following $\mathrm{pH}$ indicators were observed: in the pectoral muscle of the farm bird 5.9-6.1, in the hip part 5.86.2; in the meat of farm chickens 5.6-5.8, in the hip - 5.7 6.11. These indicators correspond to consumption standards. From the data obtained from weighing individual parts of the carcasses, we see an increase in the proportionality of the development of the pectoral muscle in the carcasses of chickens "Nasha Ryaba", which was more in percentage terms by $14.5 \%$, without bone - $14.2 \%$, without skin - $14.5 \%$, the pelvic limbs are more developed and amounted to $4.4 \%$ more and compared to muscles without skin by $5.4 \%$. An insignificant difference was observed between the relative weight of bones in the thorax of the carcasses by $0.3 \%$ the weight of the sternum from the bird farm was more for the owner. In the skin, we noticed that the weight of the household carcass is $0.3 \%$ higher than the weight of chickens "Nasha Ryaba". Bones were $1 \%$ larger in farm birds, while skin was $2 \%$ larger in farm birds than in host birds. Research carried out by cooking (boiling) and taste of poultry meat indicated the freshness and good quality of the meat. On the FoodScanLabTSFOSS analyzer, the indicators of the chemical composition of broiler chicken meat in terms of fat significantly exceed the technical specifications by $3.61 \%$ in the pelvic limb meat of "Nasha Ryaba" chickens, therefore it cannot be classified as a type of dietary meat. Histological studies have shown that the sample of the trade mark "Nasha Ryaba" has a more pronounced layer of adipose tissue, a thin layer of the dermis, muscles with pronounced fragmentation of fibers, affects the taste of the product. All private and farmer bird samples show minor signs of inflammation. From these data, we can conclude that in free-range and poultry farms, there is an infection that is expressed in minor inflammatory processes on the histological preparation, in addition, it may indicate an incorrect intensive feeding with concentrated feed of broiler chickens in order to accelerate the increase and weight gain for sale.

Key words: chickens, carcasses, muscles, farm, private household.

\section{Залежність якості м'яса курчат-бройлерів від методу вирощування}

\author{
В. В. Гуніч ${ }^{1}$ Ю. С. Стронський ${ }^{2}$ Ж. Б. Коренєва ${ }^{1}$, А. І. Голованова ${ }^{1}$, О. В. Султановська
}

${ }^{1}$ Одеський державний аграрний університет, м. Одеса, Украӥна

${ }^{2}$ Львівський національний університет ветеринарної медицини та біотехнологій імені С. 3. Гжиџького, м. Львів, Україна

ЗЗавідувач лабораторї ВСЕ ринку “Черьомушки” ТОВ “Юртал”, м. Одеса, Украӥна

Для проведення досліджень придбані на ринку м. Одеси тушки курчат-бройлерів торговельної марки “Наша Ряба” та приватних господарств Одеської області Овідіопольського району. В умовах лабораторії ветеринарно-санітарної експертизи ринку 
м. Одеси ми визначали контрольний метод визначення концентрації водневих іонів (рН). В досліджених нами зразках спостерігали такі показники рН: в грудних м'язах птиці приватних господарств 5,9-6,1, в м'язах тазостегнової частини 5,8-6,2; в м'ясі фермерських курчат відповідно 5,6-5,8 в грудних м'язах та 5,7-6,11 в тазостегнових. Дані показники відповідають нормам споживання. 3 отриманих даних зважування окремих частин тушок ми бачимо збільшення пропориійності розвитку грудного м'яза у торговельної марки “Наша Ряба” порівняно з тушками курчат з приватних господарств, шо у відсотках складала більше на 14,5 \%, без кістки - 14,2\%, без шкіри - 14,5\%, тазові кінцівки більш розвинуті і складали на 4,4 \% більше, а в порівнянні м'язів без шкіри на 5,4\%. Незначна різниия спостерігалась між відносною вагою кісток в грудному відділі тушок - на 0,3 \%, вага грудини птиці фермерської тушки була більшою за господарську. В шкірі, навпаки, ми виявили, щуо вага тушки з приватних господарств більша на 0,3\% від ваги курчат “Наша Ряба”. Вага кісток у тушок птиці з приватних господарств була більшою на 1 \%, тимчасом як шкіра складала у фермерських курей аж на 2 \% більше, ніж у господарських. Проведені дослідження пробою варіння та смакові якості м'яса птиці вказували на свіжість та доброякісність м'яса. На аналізаторі FoodScanLabTSFOSS показники хімічного складу м'яса курчат-бройлерів по показникам жиру значно перевищують власні ТУ на 3,61 \% в м'ясі тазової кіниівки курчат “Наша Ряба”, внаслідок чого його не можна зарахувати до типу дієтичного м'яса. Проведенні гістологічні дослідження показали у зразка торгівельної марки “Наша Ряба" більи виражений шар жирової тканини, тонкий шар дерми, м'язи з вираженою фрагментацією волокон, щчо впливає на смак продукту. У всіх зразках, відібраних від тушок птиці з приватних та птахофермерського господарства, виявлено незначні ознаки запального процесу. 3 проведених нами досліджень можна зробити висновок, ицо при вільному вигулі на птахофермах присутня інфекиія, яка на гістопрепаратах виражена в незначних запальних процесах, крім того, може вказувати на невідрегульовану інтенсивну відгодівлю конщентрованими кормами курчат-бройлерів, щзоб пришвидиити збільшення та набір ваги для подальшого продажу.

Ключові слова: курчата, тушки, м'язи, фермерське господарство, приватне господарство.

\section{Вступ}

Птахівництво розвинене практично в усіх районах України. Більшу частину ринку складають фермерські господарства промислового типу, які мають важливе значення для країни, оскільки забезпечують населення корисними для здоров'я продуктами харчування. Для вживання в їжу використовують як яйця, так i м'ясо. М'ясо є дієтичним і високопоживним продуктом (Gorbacheva, 1993). Найкраще м'ясо отримують від гібридного молодняку декількох різновидів курей, що вирощується в спеціалізованих умовах (Balashov, 2015). Розведення птиці вигідне, оскільки має швидкі темпи відтворення поголів'я. При цьому витрати на розведення птиці неістотні порівняно з прибутком від iii вирощування (Albuquerque \& Warnick, 1971; Fisinin et al., 2013; Godfray et al., 2018).

Тому метою нашої роботи було органолептичне та морфологічне дослідження структури м'язової тканини тушок курей, придбаних на ринку м. Одеси, а також вивчити і описати можливі варіації якості та біохімічний склад різних частин тушок курей, визначити відмінність залежно від способу вирощування, збереження повноцінності продукту харчування, раціоналізувати використання в приватних господарствах екологічного методу вирощування вільним вигулом, а не промисловим клітковим або підлоговим методом на птахофермах.

Теоретичне та практичне значення отриманих результатів дасть можливість вирішити проблеми щодо мінімізації енергетичних та економічних затрат i зменшити трудоємкість процесу вирощування зі збереженням якості м'яса птиці та забезпечити ефективне корегування відхилення якості сировини, отриманої від домашніх i фермерських курей, запобігти можливим негативним показникам, пов'язаним 3 технологічними характеристиками вирощування (Lawler, 2012; Wang et al., 2017; Papah \& Abasht, 2019).

\section{Матеріал і методи досліджень}

Об’єктом дослідження були придбані по 5 тушок курчат-бройлерів на ринку “Черьомушки” ТОВ “Юртал” м. Одеси з приватних господарств Одеської області Овідіопольського району та тушки курчат, що належать до торговельної марки (ТМ) “Наша Ряба". Предметом дослідження слугували різні частини тіла тушок, зокрема грудні м'язи та тазостегнової частини, для гістології додатково були відібрані шкіра та нирки.

При дослідженні ми застосовували визначення органолептичних показників якості м'яса курей, таких як колір, запах продукту в свіжому та вареному м'ясі. Визначення смакових якостей проводили на кафедрі нормальної і патологічної морфології та судової ветеринарії за участю співробітників кафедри. Визначення хімічного складу м'яса курей на аналізаторі FoodScanLabTSFOSS проводили в багатопрофільній лабораторії ОДАУ. Для гістологічних досліджень проводили відбір проб 3 різних ділянок тушок птахів. Зрізи фарбували гематоксиліном Караці та еозином за стандартними методиками.

\section{Результати та їх обговорення}

Вартість придбаних на ринку м. Одеси тушок курчат-бройлерів ТМ "Наша Ряба" становила 64 гривень за кілограм, а за тушки курей 3 приватних господарств з Овідіопольського району Одеської області від 70 до 90 гривень. При купівлі м'яса птиці з приватного господарства - перше, на що ми звертали увагу - це наявність відповідних документів, що засвідчують перевірку товару лабораторією ветеринарносанітарної експертизи ринку. Всі кури в роздрібній торгівлі перевіряються Службою безпеки і контролю харчових продуктів. Лабораторії ринку не мають повноважень на перевірку тушок курей, що реалізується торговими марками, оскільки всі дослідження проводяться ветеринарним лікарем птахоферми, тому єдине, що можливо було перевірити, це наявність норма- 
тивних документів у продавців фермерських курчат торговельної марки "Наша Ряба". Термін “свіжий” на етикетці для птиці стосується будь-якого сирого продукту з птиці, температура якого ніколи не була нижче ніж -3 С. Ніякого спеціального маркування не потрібно для свіжої птиці, що зберігається при температурі від -18 до $-4{ }^{\circ} \mathrm{C}$. При купівлі тушок курей ТМ "Наша Ряба" була виявлена рожева рідина в упакованому свіжому курчаті - це кров разом з водою, яка була поглинена тушкою курчати в процесі охолодження. Кров видаляється 3 птиці під час забою, i лише невелика іiі кількість залишається в м'язовій тканині. При купівлі тушки курки ми звертали увагу на колір шкіри. Колір курячої шкірки коливався від кремового до жовтого. Колір шкіри залежить від типу корму, який з'їла курка, а не від харчової цінності, смаку, ніжності або вмісту жиру. Колірні переваги неоднакові в різних частинах країни, тому виробники використовують той тип корму, який дає бажаний колір.

За кольором м'ясо тушок курей ТМ “Наша Ряба" мало блідо-рожевий відтінок, жир м'який білого кольору. При визначенні на пружність м'ясо було еластичне і щільне, при натисканні пальцем вм'ятина одразу поверталася в початкове положення. При розрізі - м'язи вологі, але не залишають вологої плями на фільтрувальному папері. Жир при стисканні та розтиранні між пальцями без запаху осалювання та прогірклості, блідий у фермерських курчат і жовтий у господарських, щільної та еластичної консистенції. Тушка ТМ “Наша Ряба" відповідала вимогам ТУ У 15.1-31398117-001-2003, за маркуванням належала до першої категорії (Class “A”). Оцінку тушок курчат приватних господарств проводили за такими показниками: у птахів дзьоб пружний, сухий i глянцевий, слизові оболонки ротової порожнини блідо-рожевого кольору, злегка вологі, сторонні запахи відсутні. Очні яблука випуклі і заповнюють орбіту. Шкіра на тушках була біла або ледь жовтувата. М'язова тканина щільна і пружна, при натисканні пальцем на грудні м'язи утворена ямка швидко вирівнюється. Запах специфічний, характерний курчатам-бройлерам. Жир перевіряли особливо в ділянці шиї і гуза, він мав жовтий колір, не тьмяний. Для визначення вологості прикладали фільтрувальний папірець на 2 секунди, волога пляма була відсутня.

Для проведення ветеринарно-санітарної оцінки тушки курчат-бройлерів 3 приватних господарств приймають напівпатрані тушки цілими разом 3 внутрішніми органами. У тушки курки з приватного господарства ми звертали увагу на стан печінки. Вона була гладкою, колір варіювався - від червоного до жовтого. Тип корму, метаболізм курки і іï порода можуть пояснити відмінності в кольорі. При дослідженні печінка була гладка, пружна і рівномірно забарвлена в темно-брунатний колір, жовчний міхур видалений.

В умовах лабораторії ринку ми проводили визначення концентрації водневих іонів (pH). (На одному дослідному зразку проводили три одиничних вимірювання). В досліджених нами зразках спостерігали такі показники $\mathrm{pH}$ : в грудному м'язі господарської птиці 5,9-6,1, в тазостегновій частині 5,8-6,2; в м'ясі фермерських курчат 5,6-5,8, в тазостегновій - 5,7-6,11. Дані показники відповідають нормам споживання.

При визначенні пропорційності розвитку м'язів різних ділянок тушок курчат-бройлерів складена таблиця № 1, де ми бачимо збільшення пропорційності розвитку грудного м'яза у тушок курчат ТМ "Наша Ряба" порівняно з господарськими, що в відсотках складав більше на 14,5\%, без кістки $14,2 \%$, без шкіри $-14,5 \%$.

\section{Таблиця 1}

Співвідношення окремих частин тушок курчат

\begin{tabular}{lcccc}
\hline \multirow{2}{*}{ Частина тушки } & \multicolumn{2}{c}{ Курчата з приватних господарств } & \multicolumn{2}{c}{ Курчата ТМ “Наша Ряба” } \\
\cline { 2 - 5 } & Абсолютна вага, г & Відносна вага, \% & Абсолютна вага, г & Відносна вага, \% \\
\hline Ціла тушка & $2064 \pm 0,05$ & 100 & $2176 \pm 0,01$ & 100 \\
Грудина з кісткою & $555 \pm 0,07$ & 26,9 & $900 \pm 0,02$ & 41,4 \\
Грудина зі шкірою без кістки & $480 \pm 0,03$ & 23,3 & $815 \pm 0,01$ & 37,5 \\
Грудина без шкіри & $383 \pm 0,03$ & 18,6 & $739 \pm 0,01$ & 33,10 \\
Тазова кінцівка & $696 \pm 0,04$ & 33,7 & $638 \pm 0,04$ & 29,3 \\
М'язи тазової кінцівки без кісток & $530 \pm 0,07$ & 25,7 & $485 \pm 0,02$ & 22,3 \\
М'язи тазової кінцівки без шкіри & $503 \pm 0,05$ & 24,4 & $414 \pm 0,03$ & 19 \\
\hline
\end{tabular}

Зовсім інша картина спостерігалася стосовно тазових кінцівок. Враховуючи, що птиця приватних господарств більше часу проводить на волі, ніж птиця на птахофермах, тазові кінцівки більш розвинуті i їхня частка складала на 4,4 \% більше, а в порівнянні м'язів без шкіри - на 5,4 \%. Незначна різниця спостерігалась між відносною вагою кісток в грудному відділі тушок - на 0,3 \% вага грудини тушки фермерської була більшою за господарську. В шкірі, навпаки, ми виявили, що вага господарської тушки більша на 0,3 \% від ваги курчат ТМ “Наша Ряба".

Зворотно пропорційні дані ми спостерігали при зважуванні тазових кінцівок: вага кісток була у господарських птахів більшою на $1 \%$, тимчасом як шкіра складала у фермерських курей аж на 2 \% більше, ніж у господарських. Такі пропорції можуть бути пов'язані з умовами утримання (господарська птиця утримується на вільному вигулі, тому кістки кінцівок мають більший відсоток ваги). Водночас, не маючи достатнього руху, шкіра, яка одночасно 3 
захисною функцією ще являє собою депо води, у фермерських курчат вага складала на 2 \% більше за господарських.

Далі ми проводили дослідження пробою варіння та визначали смакові якості м'яса птиці. Після проварювання тушок ТМ "Наша Ряба" ми спостерігали потемніння кісток. Потемніння навколо кісток відбувається насамперед у молодих бройлерів. Оскільки їхні кістки не кальциновані повністю, пігмент $з$ кісткового мозку може просочуватися через пористі кістки. Заморожування також може сприяти цьому просочуванню. Рожевий колір м'яса у безпечно приготовленої курки може бути через гемоглобін у тканинах, який може утворювати термостійкий колір. Для визначення якості бульйону 20 г м'яса птиці, взятого з різних частин тушок, намагаючись відібрати ближче до кісток, подрібнили ножицями та помістили в конічну колбу ємкістю $100 \mathrm{~cm}^{3}$, залили $60 \mathrm{~cm}^{3}$ дистильованої води, перемішали, закрили годинниковим скельцем i поставили на киплячу водяну баню на 10 хвилин. Довівши до кипіння, визначили аромат бульйону, який був специфічний для всіх зразків, але більш виражений і ароматний в бульйоні господарської птиці і слабкий в тушках курчат-бройлерів ТМ “Наша Ряба”, відповідаючи якості, свіжості та доброякісності м'яса.

Для визначення прозорості бульйону $20 \mathrm{~cm}^{3}$ налили в мірний циліндр об'ємом 25 см $^{3}$ - бульйон був достатньо прозорий 3 невеликою кількістю домішок пластівців білка в зразках від господарської курки і меншою кількістю в фермерської. На поверхні бульйону плавали незначні краплі жиру, яких було більше в зразках тушок торгової марки. Провівши порівняльну оцінку з ГОСТ 7702-74, виявили, що м’ясо повністю відповідає вимогам (таблиця № 2).

За смаковими якостями бульйон зварений 3 м'яса курчат-бройлерів приватного господарства був більш насиченим ніж 3 м'яса курчат-бройлерів ТМ “Наша Ряба". М'ясо грудини було більш жорсткішим i сухуватим на смак у тушок курей господарських, тимчасом як у м'ясі курчат ТМ “Наша Ряба” волокна були крихкими, при розрізанні в вареному стані вони розпадалися, мали слабо виражений смак. М'ясо тазостегнової частини також вирізнялось більшою жорсткістю у господарських курей, у тушок курчат TM “Наша Ряба" було більш ніжнішим і соковитим внаслідок жирових проміжків між м’язами.

\section{Таблиця 2}

Органолептична оцінка тушок курчат-бройлерів ТМ “Наша Ряба” і приватних господарств

\begin{tabular}{|c|c|c|c|}
\hline \multirow{2}{*}{ Найменування показника } & \multicolumn{3}{|c|}{ Характерні показники м’яса } \\
\hline & Птиця приватних господарств & Птиця ТМ “Наша Ряба” & ГОСТ 7702-74 \\
\hline $\begin{array}{c}\text { Зовнішній вигляд і колір } \\
\text { дзьоба }\end{array}$ & Глянцевий & - & Глянцевий \\
\hline $\begin{array}{c}\text { Слизові оболонки ротової } \\
\text { порожнини }\end{array}$ & $\begin{array}{c}\text { Блискуча, блідо-рожевого } \\
\text { кольору, вологі }\end{array}$ & - & $\begin{array}{c}\text { Блискуча, блідо-рожевого } \\
\text { кольору, незначно } \\
\text { зволожена }\end{array}$ \\
\hline Очного яблука & Випукле, рогівка блискуча & - & $\begin{array}{c}\text { Випукле, рогівка } \\
\text { блискуча. }\end{array}$ \\
\hline Поверхня тушка & $\begin{array}{c}\text { Суха, жовтувато-сірого кольору } \\
3 \text { червоним відтінком }\end{array}$ & $\begin{array}{c}\text { Місцями волога, біло- } \\
\text { жовтого кольору з рожевим } \\
\text { відтінком }\end{array}$ & $\begin{array}{c}\text { Суха, біло-жовтого } \\
\text { кольору з рожевим } \\
\text { відтінком, у нежирних } \\
\text { тушок жовтувато-сірого } \\
\text { кольору з червоним } \\
\text { відтінком }\end{array}$ \\
\hline $\begin{array}{c}\text { Підшкірна і внутрішня } \\
\text { жирова тканина }\end{array}$ & $\begin{array}{c}\text { Жир без запаху, жовтого } \\
\text { кольору, консистенція еластична } \\
\text { і щільна }\end{array}$ & $\begin{array}{c}\text { Консистенція жиру пухка, } \\
\text { блідо-жовтого кольору }\end{array}$ & $\begin{array}{c}\text { Блідо-жовтого або } \\
\text { жовтого кольору }\end{array}$ \\
\hline $\begin{array}{c}\text { Серозні оболонки грудо- } \\
\text { черевної порожнини }\end{array}$ & $\begin{array}{c}\text { Волога, блискуча без слизу i } \\
\text { плісняви }\end{array}$ & $\begin{array}{c}\text { Волога, блискуча без слизу i } \\
\text { плісняви }\end{array}$ & $\begin{array}{c}\text { Волога, блискуча без } \\
\text { слизу і плісняви }\end{array}$ \\
\hline М'язи на розрізі & $\begin{array}{c}\text { Злегка вологі, не залишають } \\
\text { вологої плями на } \\
\text { фільтрувальному папері, } \\
\text { рожевого кольору }\end{array}$ & $\begin{array}{l}\text { Злегка вологі, залишають } \\
\text { незначні вологі плями на } \\
\text { фільтрувальному папері, } \\
\text { блідо-рожевого кольору }\end{array}$ & $\begin{array}{c}\text { Злегка вологі, не } \\
\text { залишають вологої плями } \\
\text { на фільтрувальному } \\
\text { папері, блідо-рожевого } \\
\text { кольору }\end{array}$ \\
\hline Консистенція & $\begin{array}{c}\text { М'язи щільні, пружні, при } \\
\text { натисканні пальцем утворена } \\
\text { ямка швидко вирівнюється }\end{array}$ & $\begin{array}{c}\text { М'язи менш щільні та менш } \\
\text { пружні, при натисканні } \\
\text { пальцем утворена ямка, яка } \\
\text { вирівнюється через хвилину }\end{array}$ & $\begin{array}{c}\text { М'язи щільні, пружні, при } \\
\text { натисканні пальцем } \\
\text { утворена ямка швидко } \\
\text { вирівнюється }\end{array}$ \\
\hline Запах & $\begin{array}{c}\text { Специфічний, властивий } \\
\text { свіжому м’ясу курки }\end{array}$ & $\begin{array}{c}\text { Дуже слабкий, майже не } \\
\text { відчувається }\end{array}$ & $\begin{array}{c}\text { Специфічний, властивий } \\
\text { свіжому м’ясу курки }\end{array}$ \\
\hline Прозорість і запах бульйону & $\begin{array}{c}\text { Прозорий, ароматний з } \\
\text { невеликою кількістю домішок } \\
\text { пластівців }\end{array}$ & $\begin{array}{c}\text { Прозорий, зі слабким } \\
\text { запахом, специфічним для } \\
\text { курей, на поверхні незначна } \\
\text { кількість жиру }\end{array}$ & Прозорий, ароматний \\
\hline
\end{tabular}


Для роботи на аналізаторі FoodScanLabTSFOSS ми відібрали зразки м'язів грудини та тазостегнової частини у домашньої і птахофермерської тушки курчат. Після ідентифікації даних щодо м'яса курей результати ми навели в таблиці 3.

При порівнянні показників хімічного складу м'яса курчат-бройлерів приватних господарств і ТМ “Наша Ряба" з ТУ У 15.1-31398117-001-2003, згідно з яким реалізується вся фермерська птиця, ми дійшли таких висновків: за протеїном м'ясо згідно з ТУ, причому м'ясо ТМ "Наша Ряба" незначно, але перевищує показники господарських. Показники жиру перевищують власті ТУ на 3,61 \% в м'ясі тазової кінцівки курчат ТМ “Наша Ряба", внаслідок чого його не можна зарахувати до типу дієтичного м'яса, на відміну від курчат з приватного сектору, в м'ясі яких жиру було менше за ТУ на $0,5 \%$.

\section{Таблиця 3}

Результати масової долі показників у зразках тушок курчат-бройлерів ТМ “Наша Ряба” і приватних господарств, \%

\begin{tabular}{lrrrrr}
\hline \multirow{2}{*}{ Показники } & \multicolumn{2}{c}{ Тушка курчат з приватних господарств } & \multicolumn{2}{c}{ Тушка курчат ТМ “Наша Ряба” } & ТУ У 15.1- \\
\cline { 2 - 5 } & Грудина & Стегно & Грудина & Стегно & 31398117-001-2003 \\
\hline Протеїн & $20,11 \pm 0,04$ & $19,5 \pm 0,06$ & $21,35 \pm 0,01$ & $19,61 \pm 0,03$ & $\geq 19$ \\
Жир & $1,3 \pm 0,03$ & $1,33 \pm 0,05$ & $1,8 \pm 0,02$ & $5,41 \pm 0,03$ & $\leq 1,8$ \\
Колаген & $0,75 \pm 0,07$ & $0,85 \pm 0,04$ & $0,72 \pm 0,03$ & $1,25 \pm 0,02$ & - \\
Волога & $78,74 \pm 0,08$ & $79,7 \pm 0,06$ & $76,32 \pm 0,02$ & $74,13 \pm 0,01$ & - \\
\hline
\end{tabular}

Такі показники, як вологість, були майже на одному рівні - у господарської тушки вона була більшою на 2,42 \% в грудному м'язі і на $5,57 \%$ в тазостегновій частині. Найбільше колагену виявлено в м'язах тазостегнової частини курчат ТМ “Наша Ряба", що на $0,4 \%$ більше, ніж у м'язах цієї ж частини тушок курчат-бройлерів приватних господарств.

Для проведення гістологічного дослідження ми відібрали шматочки м'язів $з$ кожної ділянки тушок курчат і провели морфологічне дослідження грудини та тазостегнової частини, шкіри й нирок птахів.

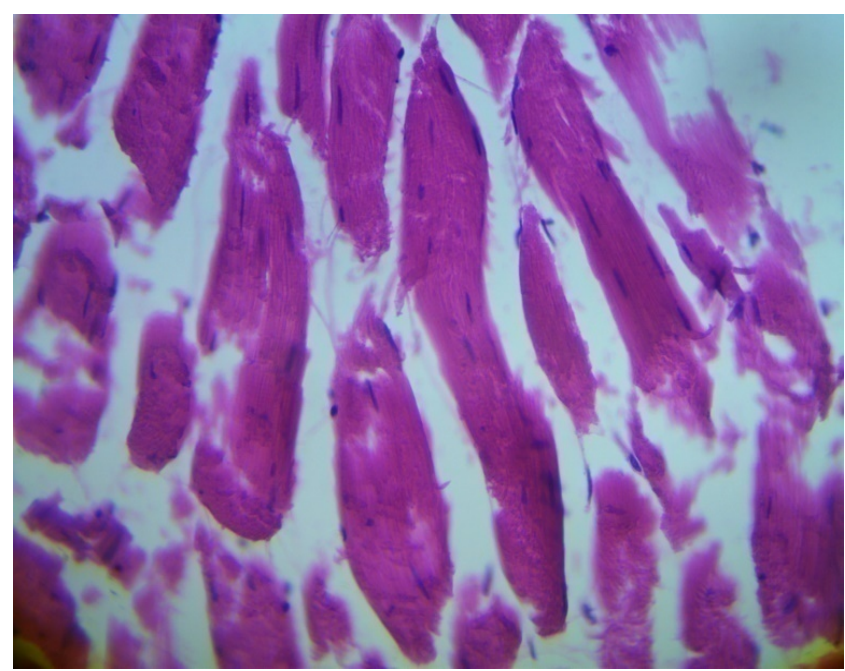

Рис. 1. Грудний м'яз. Набряк міжм'язового простору, слабо виражені дистрофічні зміни волокон, вогнищеве зникнення поперечної посмугованості. Гематоксилін Караці та еозин х400

При гістологічному дослідженні шкірного покриву ми виявляли помірний набряк дерми, клітковини, сухожильних волокон i пір'євих м'язів. Шар клітковини був слабо виражений. Часто у клітковині виявляли невеликі лімфогістіоцитарні інфільтрати.
Першими в дослідженні ми використали матеріал, відібраний від тушок курчат-бройлерів 3 приватних господарів. При цьому в м'язах грудини ми спостерігали виражений набряк міжм'язових просторів (рис. 1, рис. 2), вогнищеве набрякання волокон, слабо виражені дистрофічні зміни волокон, каріопікноз, набрякання цитоплазми. В міжм'язових просторах спостерігали дрібні вогнищеві, рідше дифузні запальні лімфогістіоцитарні інфільтрати.

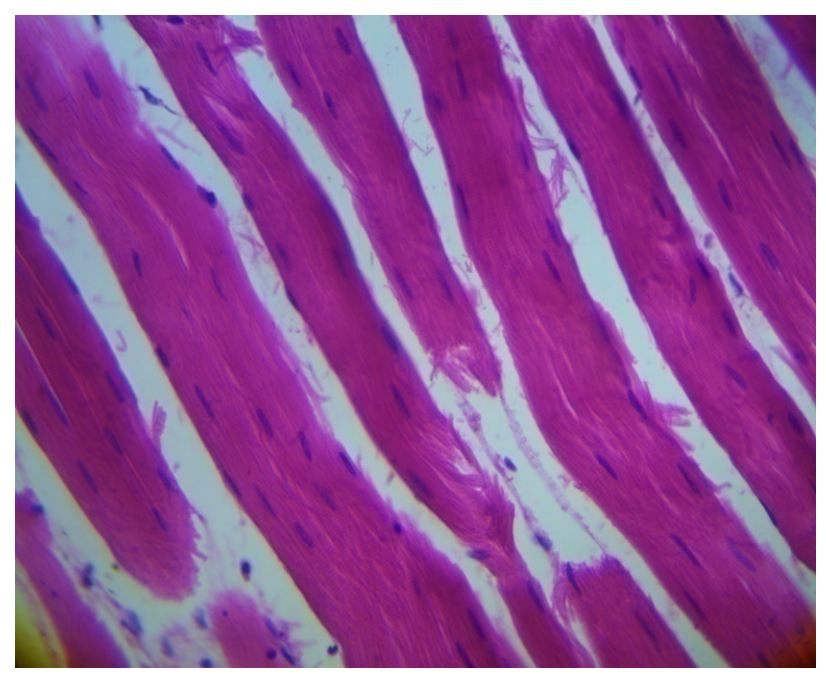

Рис. 2. Грудний м'яз. Набряк міжм'язового простору, слабо виражені дистрофічні зміни волоконкаріопікноз, вогнищеве набрякання волокон, вогнищеве зникнення поперечної посмугованості. Гематоксилін Караці та еозин х400

У м'язах тазостегнової частини тушок господарських птахів при гістологічному дослідженні спостерігали набряк міжм'язових просторів, набряк м'язових волокон, слабо виражені дистрофічні зміни волокон, каріопікноз, набряки та дегомогонізацію цитоплазми. 
Із внутрішніх органів, які ми могли дослідити спільно, як у господарської, так і фермерської птиці були тільки нирки. В птахів приватного господарства нирки мали збережену структуру, клубочки були дрібні. Також ми виявляли наявність гідропічної дистрофії епітелію звивистих канальців та поодинокі дрібні поліморфноклітинні запальні інфільтрати в стромі.

При дослідженні м’язів грудини ТМ “Наша Ряба” ми спостерігали набряк міжм'язових просторів,



Рис. 3. Грудний м'яз. Набряк міжм'язового простору, фрагментація волокон, острівець жирової тканини в міжм'язовому просторі. Гематоксилін Караці та еозин $\mathrm{x} 100$

При мікроскопічному дослідженні тазостегнових м'язів виявляли слабо виражені дистрофічні зміни вогнища набухання волокон, набряки в міжм'язових просторах, каріопікноз, дрібні фокуси дегомогенізації цитоплазми. Як і в грудних, в тазостегнових м'язах також спостерігали фрагментацію м'язевих волокон.

При гістологічному дослідженні виявлено, що нирки у птахофермерських курчат мали збережену структуру, клубочки дрібні, але, як і в господарських птахів, теж виявляли ознаки помірної гідропічної дистрофії епітелію звивистих канальців.

При проведенні порівняння результатів дослідження гістологічних препаратів, отриманих від тушок курчат-бройлерів ТМ "Наша Ряба" та господарських, ми можемо сказати, що в курчат ТМ більш товсті м'язові волокна, у міжм'язових просторах дрібні ділянки жирової тканини; в обох зразках слабо виражена ступінь дистрофії. У зразках птиці приватних господарств домінує набухання i дегомонізація цитоплазми, в фермерських птахів фрагментація волокон. У зразках тушок ТМ “Наша Ряба" тонший шар дерми, значно ширший шар жирової тканини в шкірі, але менш виражені дистрофічні зміни в нирках та у м'язах і шкірі відсутні запальні інфільтрати.

3 цих даних можна зробити висновок, що при вільному вигулі все ж таки буде присутня інфекція, про що свідчать наявні незначні запальні процеси, також таку картину може показувати незбалансована осередки фрагментації волокон (рис. 3, рис. 4), вогнища набухання волокон i цитоплазми, слабо виражені дистрофічні зміни волокон, каріопікноз, а також вогнища острівців жирової тканини в міжм'язових просторах.

При дослідженні шкіри виявили різко потоншений шар епідермісу, а сама дерма тонка. Також спостерігали слабкий набряк дерми, клітковини, сухожильних волокон, при цьому шар жирової клітковини виражений значно.

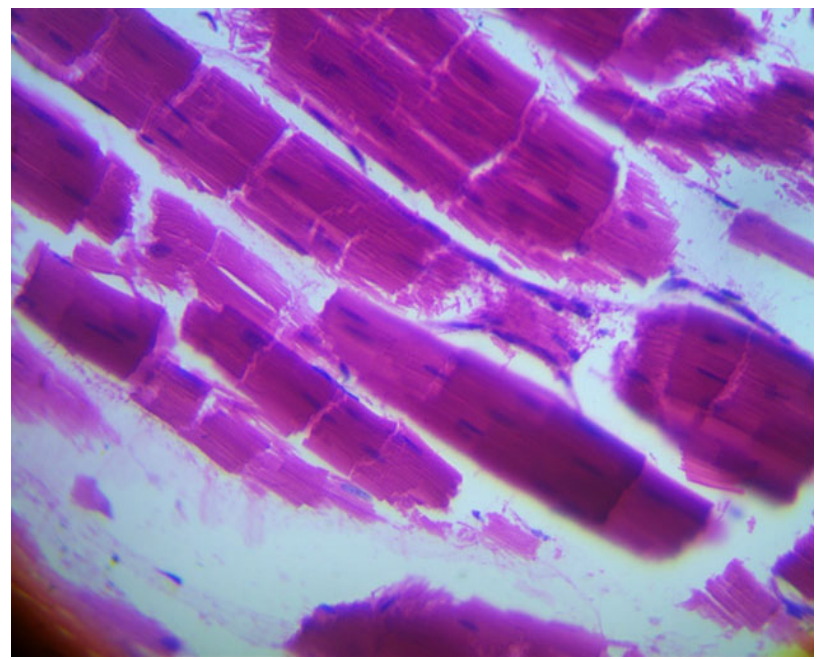

Рис. 4. Грудний м’яз. Набряк, фрагментація волокон. Гематоксилін Караці та еозин х400

інтенсивна відгодівля концентрованими кормами курчат-бройлерів 3 метою пришвидшення росту та ваги для подальшого продажу.

Фрагментація м'язових волокон, яку ми спостерігали при дослідженні препаратів, отриманих від курчат-бройлерів ТМ “Наша Ряба", найімовірніше - пов'язана 3 електростимуляцією м’яса перед підморожуванням.

Електростимуляція м'яса перед підморожуванням дозволяє значно скоротити терміни дозрівання i використання м'яса у виробництві. Електростимуляція призводить до швидкого зниження рН м'яса, що викликає швидше задубіння. Після електростимуляції максимальне посмертне задубіння м'яса спостерігається через 24 год. Гістологічні дослідження м'яса, підданого електростимуляції в різні періоди аутолізу, показали, що така обробка прискорює дозрівання м'яса. В нашому дослідженні також показано, що при цьому руйнуються м'язові волокна у вигляді фрагментації, це не завжди позитивно впливає на смак продукту.

\section{Висновки}

На підставі результатів власних досліджень ми отримали певну інформацію, завдяки якій можемо зробити такі висновки:

1. За ціновою політикою вартість за 1 кілограм тушки ТМ “Наша Ряба" в середньому складала 
64 гривні, за тушки курей з приватного господарства - 80 гривень, що на 24 \% дорожче від фермерських тушок курчат-бройлерів.

2. При вивченні органолептичних показників ми дійшли висновку, що на ринках реалізуються тушки курей, які відповідають категорії А, згідно з вимогами ГОСТ 7702-74.

3. При зважуванні окремих груп м'язів тушок курчат грудний м'яз у ТМ “Наша Ряба" порівняно 3 господарськими був більшим на 14,5 \%, що скоріш відповідає породним особливостям. Група тазостегнових м'язів птиці приватних господарств, внаслідок вільного вигулу, на 4,4 \% більша, порівняно з ТМ “Наша Ряба".

4. При дослідженні хімічного складу м’яса курчатбройлерів на аналізаторі FoodScanLabTSFOSS порівняно 3 нормативним документом ТУ У 15.131398117-001-2003 визначили, що протеїн м'яса ТМ “Наша Ряба" перевищує показники господарських на $1,24 \%$, тазостегнова частина на $0,11 \%$, а жир перевищує ТУ на 3,61 \%.

5. Гістологічні дослідження показали у зразках ТМ “Наша Ряба" більш виражений шар жирової тканини, тонкий шар дерми, м'язи з вираженою фрагментацією волокон. У всіх зразках птиці приватних i фермерських господарств незначні ознаки запалених процесів.

Перспективи подальших досліджень спрямовані на виявлення інфекційних захворюваннях у курчатбройлерів, що вирощуються в приватних господарствах, які можуть впливати на якість продукції та наносити збитки господарям. Визначити, які ветеринарно-санітарні та профілактичні заходи можуть впливати на маркування “Еко-продукт”.

Відомості про конфлікт інтересів. Автори стверджують про відсутність конфлікту інтересів щодо їх вкладу та результатів досліджень.

\section{References}

Albuquerque, E. X., \& Warnick, J. E. (1971). Electrophysiological Observations in Normal and Dystrophic Chicken Muscles. Science, 172(3989), 1260-1263. doi: 10.1126/science.172.3989.1260.

Balashov, I. (2015). Kury mjasnyh porod. Jeksmo; Moskva. URL: https://ru.pdfdrive.com (in Russian).

DSTU 8219:2015. Ptytsia sviiska. Tekhnolohichnyi protses vyroshchuvannia kurchat-broileriv. Zahalni vymohy. Chynnyi vid 2017-04-01. Kyiv: UkrNDNTs, III (Natsionalnyi standart Ukrainy) (in Ukrainian).

Fisinin, V. I., Suraj, P. F., Kuznecov, A. I., Miftahutdinov, A. V., \& Terman, A. A. (2013). Stressy i stressovaja chuvstvitel'nost' kur v mjasnom pticevodstve. Diagnostika i profilaktika: Monografija. Troick (in Russian).

Godfray, H. C. J., Aveyard, P., Garnett, T., Hall, J. W., Key, T. J., \& Lorimer, J. (2018). Meat consumption, health, and the environment. Science, 361(6399), eaam5324. doi: 10.1126/science.aam5324.

Gorbacheva, N. (1993). Porody kur i ih soderzhanie v priusadebnom hozjajstve. M.: Iskusstvo i moda (in Russian).

Lawler, A. (2012). From Farmyard to the Lab. Science, 338(6110), 1022-1023. doi: 10.1126/science.338. 6110.1022 .

Papah, M. B., \& Abasht, B. (2019). Dysregulation of lipid metabolism and appearance of slow myofiber-specific isoforms accompany the development of Wooden Breast myopathy in modern broiler chickens. Sci Rep., 9, 17170. doi: 10.1038/s41598-019-53728-8.

Wang, Y., Sun, J., Zhong, H. et al. (2017). Effect of probiotics on the meat flavour and gut microbiota of chicken. Sci Rep, 7, 6400. doi: 10.1038/s41598-01706677-z. 